\title{
Article
}

https://doi.org/10.11646/phytotaxa.303.3.6

\section{A new polyploid species of Mecardonia (Gratioleae, Plantaginaceae) from South America}

\author{
JULIÁN A. GREPPI ${ }^{1}$, MARÍA DE LAS MERCEDES SOSA ${ }^{2,3 *}$ \& MASSIMILIANO DEMATTEIS ${ }^{2,3}$ \\ ${ }^{I}$ Instituto de Floricultura, Instituto Nacional de Tecnología Agropecuaria, De los Reseros y Las Cabañas s/n ${ }^{\circ}$, Hurlingham 1686, Bue- \\ nos Aires. Argentina. \\ ${ }^{2}$ Instituto de Botánica del Nordeste (UNNE-CONICET), Casilla de Correo 209, W3400CBL Corrientes, Argentina. \\ ${ }^{3}$ Facultad de Ciencias Exactas y Naturales y Agrimensura, Universidad Nacional del Nordeste, Av. Libertad 5460, 3400, Corrientes, \\ Argentina. \\ *Author for correspondence.E-mail:mdlmsvg@yahoo.com.ar
}

\begin{abstract}
Mecardonia reneeae, a new species from northeastern Argentina, is described and illustrated. This taxon has certain resemblance to $M$. procumbens var. flagellaris, but can be easily distinguished by the combination of life form, aspect of the plant, root and stem type, sepal width, fruit size, and chromosome number $(2 n=4 x=44)$. A key to distinguish it from related species is also provided.
\end{abstract}

\section{Introduction}

Mecardonia Ruiz \& Pavon (1794: 95) is a New World genus of the tribe Gratioleae (Plantaginaceae). It is characterized by annual or perennial herbs with erect or creeping habit, densely branched, mostly glabrous, glandular-punctate leaves, pedicels basally bibracteolate, yellow and white flowers, and anther thecae separated by an arm-like connective tissue (D'Arcy 1979). In the review by Rossow (1987), 10 species of Mecardonia distributed from the east coast of the United States to Argentinian Patagonia and Central Chile were considered. This number of species was modified by Souza (1997) and Souza \& Giulietti (2009), who suggested seven species and established the center of diversification including Rio Grande do Sul (Brazil), Uruguay and northeastern Argentina. Recently, another species from Argentina was described: M. kamogawae Greppi \& Hagiwara (2011: 44). However further studies are needed to clearly delimit the M. procumbens complex.

The chromosome number of Mecardonia species revealed that the genus has diploid and polyploid taxa (Sosa et al. 2016). Mecardonia grandiflora (Bentham 1836: 56) Pennell (1946: 87), M. procumbens (Miller 1768: 6) Small (1903: 1338) var. procumbens and M. procumbens var. flagellaris (Chamisso \& Schlechtendal 1827: 575) Souza (1997: $186)$ are diploid $(2 \mathrm{n}=22)$, whereas $M$. kamogawae is hexaploid $(2 \mathrm{n}=66)$. Polyploidization has been recognized as an important process in plant evolution (Stebbins 1971, Grant 1989, Otto \& Whitton 2000, Soltis et al. 2004). Polyploidy is a common phenomenon present in genera of Plantaginaceae, such as Antirrhinum Linnaeus (1753: 612), Cymbalaria Hill (1756: 113), Chelone Linnaeus (1753: 611), Digitalis Linnaeus (1753: 621), Linaria Miller (1754: 2), Plantago Linnaeus (1753: 112), Stemodia Linnaeus (1759: 1118), and Veronica Linnaeus (1753: 9) (Hair 1966, Subramanian \& Pondmudi 1987, Sosa \& Seijo 2002, Sosa et al. 2009, 2011, Wolfe et al. 2002, Vargas et al. 2004, Murray et al. 2010, Castro et al. 2012, Wong \& Murray 2012, Ranjbar \& Nouri 2015). Previous studies show that in Stemodia, diploids and polyploids are quite different in morphological and anatomical features (Sosa et al. 2012, Sosa \& Dematteis 2014).

The results of a comparative morphological and cytological analysis in Mecardonia, allowed us to identify Mecardonia reneeae as a new species, which is here described. Additionally, an identification key including morphologically similar species is provided. 


\section{Materials and methods}

\section{Field study and plant collection}

Material of the new species was collected in the field; part of this material was prepared for herbarium collection, whereas some fruit and flower samples were stored for cytological and micromorphological studies. In addition, some plants were grown in greenhouses. Herbarium material is deposited at BAB, SI.

\section{Cytological studies}

Mitotic chromosome preparations were made from root meristems. The roots were pretreated in $0.002 \mathrm{M} 8$ hydroxyquinoline solution at room temperature for about $3 \mathrm{~h}$, fixed in 5:1 absolute alcohol/lactic acid (Fernández 1973) and kept in $70 \%$ ethanol at $4^{\circ} \mathrm{C}$ until analysis. Roots tips were stained following Feulgen's technique, and meristems were macerated and squashed in a drop of lactopropionic orcein (Dyer 1963). Permanent microscope slides were prepared in Euparal using the method of Bowen (1956) and examined and photographed under a Carl Zeiss microscope equipped with a Canon Power Shot A 640 digital camera.

\section{Taxonomic treatment}

Mecardonia reneeae Greppi \& Sosa, sp. nov. (Figs. 1-2, Table 1)

Type:-ARGENTINA. Corrientes. Dep. Empedrado, Ruta Provincial 6 y arroyo Empedrado [27 48’S, 58³0’W], 20 December 2005. Greppi \& Hagiwara 560 (holotype BAB!, isotype SI!).

Diagnosis:-A Mecardonia procumbens var. flagellaris similis, sed habitu terophyto, caulibus erectis, radicibus gemmiferis, foliis serratis, petalis angustis, deltoideis et linearibus, fructus minore, chromosomatum numero tetraploideo $2 n=44$ (contra $2 n=22$ ).

Terophyte, 15-17(-20) cm high. Roots gemiferous. Stems erect, quadrangular, glabrous, $1 \mathrm{~mm}$ diam., internodes 5-20 mm long. Leaves opposite, sessile, narrowly elliptic, 6-16(-20) $\times 2-5(-6) \mathrm{mm}$, margin serrate, base attenuate. Bracteoles 3-7 $\times$ 0.5-1.5 mm, linear, margin entire to denticulate. Pedicels 10-35(-40) mm long, erect, flexuous. Flowers one or two per node, 10-16 mm long, yellow with chestnut streaks in the throat. Calyx 5-7 mm long; sepals narrowly deltoid to linear, acute, dorsal sepal 5-7(-10) $\times 1-1.2 \mathrm{~mm}$; two ventral sepals 5.5-7(-8) $\times 0.8-1(-3) \mathrm{mm}$; two lateral sepals 4-6(-8) × 0.3-0.6 mm. Corolla 8-14 × 6-8 mm, posterior lip 6-8 $\times 6-7 \mathrm{~mm}$, entire, briefly apiculate, internally pubescent at base; middle lobe of frontal lip 6-7 $\times 7-8.5 \mathrm{~mm}$; broadly obovate, glabrous; lateral lobes of equal size, sometimes obovate. Stamens 4, anterior filaments $5 \mathrm{~mm}$ long, posterior $4 \mathrm{~mm}$ long, all inserted at the base and reaching half of the corolla tube length. Ovary ellipsoid, $3 \mathrm{~mm}$ long; style $3-4 \mathrm{~mm}$ long. Capsule ellipsoid, light brown, 3-5 × 1.5-1.8 mm. Seeds, $0.4-0.5 \times 0.3-0.4 \mathrm{~mm}$, rough, blackish.

Distribution, habitat and phenology:-Mecardonia reneeae grows in open and humid areas, low clayey loam soils near watercourses, or border of streams in eastern Formosa, Chaco, northwest of Corrientes and northeast of Santa Fe in Argentina, within the Chaco phytogeographic province (Cabrera 1976). The species flowers from August to March.

Etymology:-The specific epithet is dedicated to Renée H. Fortunato, Argentinean botanist dedicated to the study of Leguminosae.

Additional specimens examined:-ARGENTINA. Prov. Chaco: Dep. Bermejo, Las Palmas, 14 November 1983, Fortunato et al. 607 (BAB); Dep. Primero de Mayo, Colonia Benítez, 10 June 1959, Schulz 10437 (BAB). Prov. Corrientes: Dep. Capital, near to Ingenio Primer Correntino, 18 Km NE of Corrientes, 15 September 1982, Schinini \& Martínez-Crovetto 2636 (CTES); $5 \mathrm{Km}$ E of Laguna Brava, 29 August 1970, Krapovickas \& Cristóbal 15836 (CTES); $10 \mathrm{Km}$ E of Laguna Brava, route 5, 21 August 1970, Krapovickas \& Cristóbal 16099 (CTES); Parques de la Facultad de Ciencias Agrarias, 23 August 1974, Quarín 2403 (CTES); Molina Punta, November 1978, Arbo 1562 (CTES); Perichón, 8 September 1975, Schinini 11601 (CTES); Dep. San Cosme, Paso de la Patria, 12 August 1967, Krapovickas \& Cristóbal 1302 (CTES); Desvío a Pto. González, 9 Km. near to Paso de la Patria, 10 September 1971, Tressens et al. 168 (CTES); Dep. San Luis del Palmar, $10 \mathrm{Km}$ SE of San Luis del Palmar, Route 6, 26 September 1973, Quarín \& Tressens 1349 (CTES). Prov. Formosa: Dep. Pilcomayo, Parque Nacional Pilcomayo, near to Puerto Soledad, 9 November 1991, Fortunato et al. 2097 (BAB, SI). Prov. Santa Fe: Dep. Gral. Obligado, Villa Ana, 18 August 1973, Quarín 1193 (CTES). 


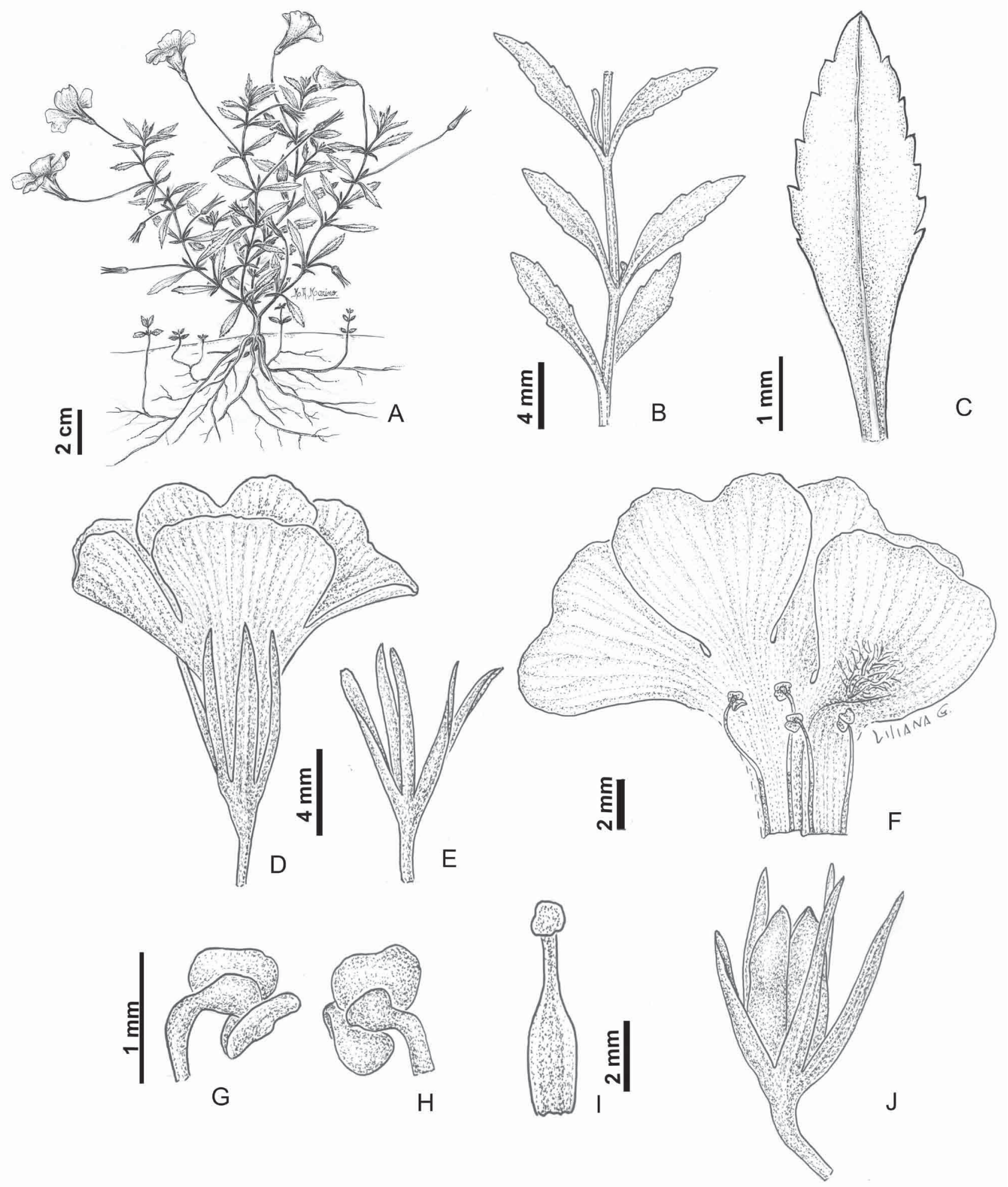

FIGURE 1. Mecardonia reneeae. A: Habit. B: Stem. C: Detail of the leaf. D: Flower in lateral view. E: Calyx. F: Dissected corolla. G: Anterior anther. H: Posterior anther. I: Gynoecium. J: Fruit (A-C: from Greppi \& Hagiwara 560, BAB; illustrated by M. Marino; B-J: from Schinini 11601, CTES; illustrated by Mirtha L. Gómez). 

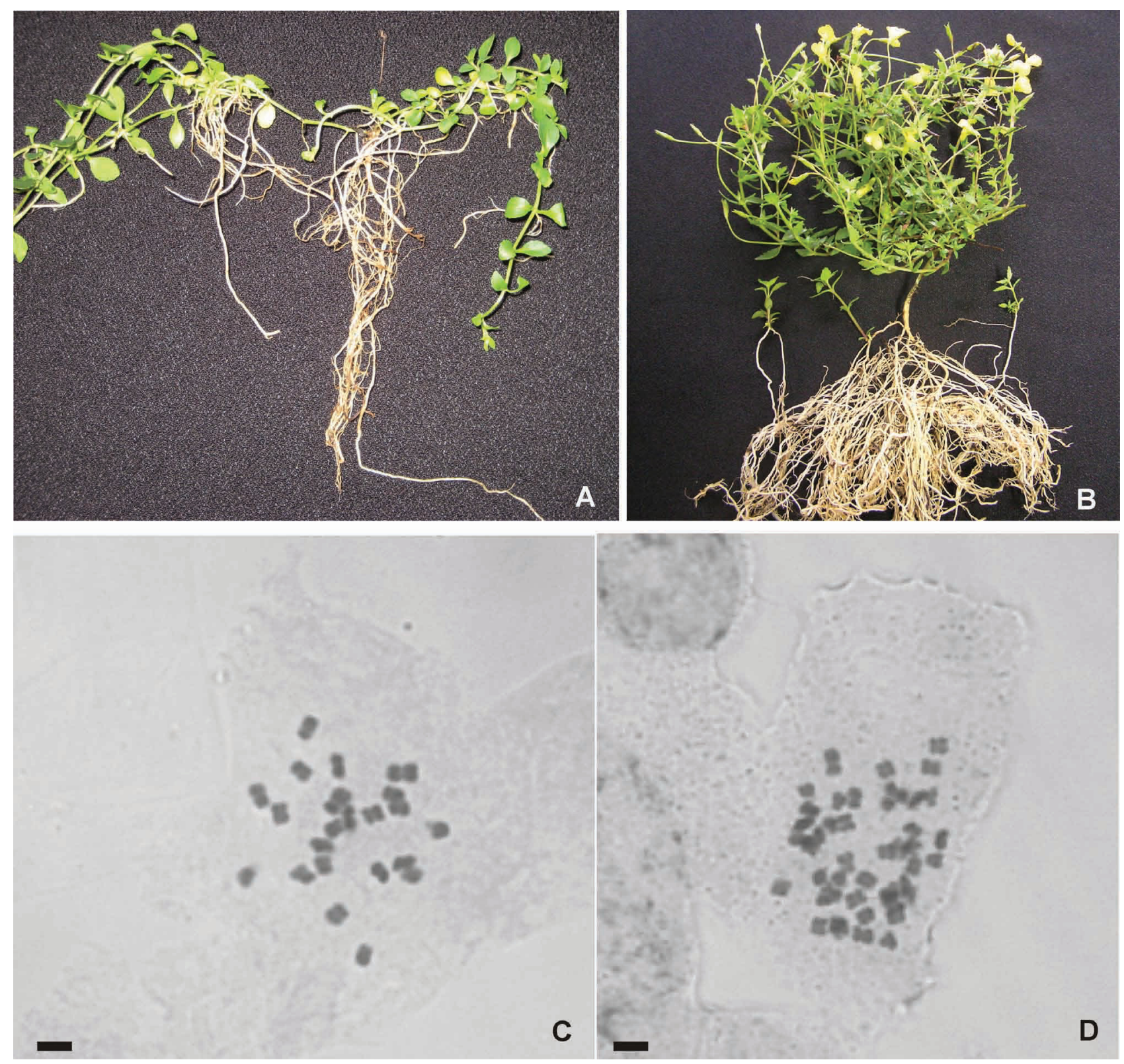

FIGURE 2. A, C: Mecardonia procumbens var. flagellaris. A. Habit, C. Metaphase image showing 22 chromosomes. B, D. M. reneeae. B. Habit. D. Metaphase image showing 44 chromosomes.

TABLE 1. Comparison of diagnostic characters between Mecardonia procumbens var. flagellaris, M. reneeae and M. kamogawae.

\begin{tabular}{llll}
\hline & M. procumbens var. flagellaris & M. reneeae & M. kamogawae \\
\hline Life forms & camephyte decumbent & terophyte & geophyte \\
Stems & repens, radicant, stoloniferous & not radicant & not radicant \\
Root & not gemmiferous & gemmiferous & gemmiferous \\
Leaf margin & entire & serrate & serrate \\
Form leaf & linear to narrow elliptical & narrow elliptic & ovate to broadly elliptic \\
Consistency of the leaf & herbaceous & herbaceous & slightly succulent \\
Bracteoles (mm) & $5-11 \times 0.5-2$ & $3-7 \times 0.5-1.5$ & $6-12 \times 2-4$ \\
Dorsal sepal width (mm) & $1.5-3$ & $1-1.2$ & $1.5-2$ \\
Capsule size (mm) & $5-9 \times 2-4$ & $3-5 \times 1.5-1.8$ & $5-6 \times 3-3.5$ \\
Chromosome numbers & $2 \mathrm{n}=22$ & $2 \mathrm{n}=44$ & $2 \mathrm{n}=66$ \\
\hline
\end{tabular}




\section{Discussion}

We confirmed a chromosome number of $2 \mathrm{n}=4 \mathrm{x}=44$ in Mecardonia reneeae (Fig. 2), as reported with the name Mecardonia sp. in Sosa et al. (2016). This taxon differs from other similar taxa that are diploid $(2 \mathrm{n}=2 \mathrm{x}=22)$, such as M. procumbens var. flagellaris, or hexaploid, such as $M$. kamogawae $(2 \mathrm{n}=2 \mathrm{x}=66)$.

Morphologically, Mecardonia reneeae is similar to M. kamogawae in terms of the gemiferous root system (Fig. 2) but can be distinguished by the sepal width, consistence and color of leaves, bracteole length and fruit size. Furthermore, some materials of this new species were mistaken for M. procumbens var. flagellaris in the past. However, both species can be easily distinguished when studying living plants. Mecardonia procumbens var. flagellaris are plants with radicating stems, occasionally somewhat ascending at the ends; the stems and its branches grow up to 40 or 50 $\mathrm{cm}$ in length, spreading across the ground and producing adventitious roots; it does not have gemiferous roots; its appearance is not compact. In addition, the combination of erect and non-radicant stems and gemmiferous roots gives $M$. reneeae a compact appearance. The margin leaves of $M$. procumbens var. flagellaris are entire or sub-serrate and the sepals, mainly the dorsal sepal, are wider $(1.5-3 \mathrm{~mm} v s .1-1.2 \mathrm{~mm}$ in width), and the fruits are bigger $(5-9 \times 2-4$ $\mathrm{mm} v$ s. $3-5 \times 1.5-1.8 \mathrm{~mm}$ ) than those of $M$. reneeae.

These species were also found to differ in their life form. During the winter season, when visiting different natural populations of Mecardonia, we observed that M. procumbens var. flagellaris maintains aerial shoots latent, whereas M. reneeae plants disappear completely and grows again when the new spring season approaches. According to the classification of Raunkiær (1934, modified by Ellenberg \& Mueller-Dombois, 1966), M. procumbens var. flagellaris would behave as a camephyte species, whereas $M$. reneeae would be terophyte.

The results obtained from the intra- and inter-specific crosses in native Mecardonia species indicated that in the intraspecific crosses $M$. reneeae produced $100 \%$ of fruits with a high percentage of viable seeds. However, the interespecific crossses with $M$. procumbens var. procumbens, M. procumbens var. flagellaris, M. kamogawae and $M$. grandiflora produced no capsules. According to this result, M. reneeae is reproductively isolated from M. procumbens var. procumbens, M. procumbens var. flagellaris, M. grandiflora and M. kamogawae, and is therefore considered a valid species. The information of crosses is being processed for immediate publication.

There is also a distinction in the distribution among these three species. Mecardonia reneeae is restricted to northern Argentina; it grows in Chaco province (Cabrera \& Willink 1973, Cabrera 1976), in low clayey loam soils near watercourses in areas near Paraná River. Mecardonia kamogawae is endemic to the center-east of Corrientes province; it grows in sandy soils, near Uruguay River. In contrast, M. procumbens var. flagellaris is widely distributed from Mato Grosso do Sul (Brazil) to Chubut (Argentina), including areas in Chile, Paraguay and Uruguay, and covering more phytogegraphic provinces. This pattern of cytotype distribution is characteristic of young polyploid complexes (Stebbins 1971). In these complexes, the geographic ranges of polyploid cytotypes are more restricted than those of diploids, but their ranges overlaps with those of the diploid species; thus, this overlap might contribute genomes to the tetraploid species, determining some degree of sympatry among these species.

In conclusion, $M$. reneeae seems to be closely related to M. kamogawae and in the past some materials of this new species were mistaken for M. procumbens var. flagellaris. We found that the combination of the morphological and chromosome characters, with geographical range information provides a satisfactory identification of nearly all specimens.

\section{Key to M. reneeae and similar species}

1. Stems prostrate, radicants, stoloniferous, sometimes with erect or ascending branches born from the prostrate stems. Root system not gemmiferous. Leaves entire. M. procumbens var. flagellaris

Stems erect, not radicants, gemmiferous root system. Leaves serrate.

2. Leaves herbaceous, narrowly elliptical, concolorous. Bracteoles 3-5 × 0.5-1.5 mm. Pedicels up to 35(-40) mm. Dorsal sepal 1-1.2 mm wide. Capsule 3-5 × 1.5-1.8 mm. ....................................................................................................... M. reneeae Leaves slightly succulent, ovate to broadly elliptical, discolorous. Bracteoles $6-12 \times 2-4 \mathrm{~mm}$. Pedicels up to $65 \mathrm{~mm}$. Dorsal sepal 1.5-2 mm wide. Capsule 5-6 $\times 3-3.5 \mathrm{~mm}$ M. kamogawae 


\section{Acknowledgements}

The first author thanks the Direction of Natural Resources of the Corrientes province, also to Tomohiro Kamogawa and Juan Carlos Hagiwara for the support during the Collection trip when the type specimen was collected. We would especially like to thank the keepers and staff of the visited herbaria for their collaboration. The drawing of the species was prepared by Mirtha Liliana Gómez of the Instituto de Botánica del Nordeste and María Angélica Marino of the Instituto Nacional de Tecnología Agropecuaria. This work has been supported by grants from the Consejo Nacional de Investigaciones Científicas y Tecnológicas (CONICET), and the Secretaría General de Ciencia y Técnica of the Universidad Nacional del Nordeste (SGCyT-UNNE).

\section{References}

Bentham, G. (1836). Observations on some new, or little known genera and species of Scrophulariaceae. Companion to the Botanical Magazine 2: 56.

Bowen, C.C. (1956) Freezing by liquid carbon dioxide in making slides permanent. Stain Technology 31: 87-90. http://dx.doi.org/10.3109/10520295609113782

Cabrera, A.L. (1976) Regiones fitogeográficas argentinas. Ed. Acme, Buenos Aires, 85 pp.

Cabrera, A.L. \& Willink, A. (1973) Biogeografía de América Latina.-Monografía No 13. Secretaría General de la Organización de los Estados Americanos, Programa Regional de Desarrollo Científico y Tecnológico, Washington, DC (USA), 120 pp.

Castro, M., Castro, S. \& Loureiro, J. (2012) Genome size variation and incidence of polyploidy in Scrophulariaceae sensu lato from the Iberian Peninsula. AoB PLANTS 2012: pls037.

https://doi.org/10.1093/aobpla/pls037

Chamisso, A. \& Schlechtendal, D. (1827) De plantis in expeditione speculatoria Romanzoffiana observatis disserere pergunt. Scrophularineae. Linnaea 2: 555-609.

Ellenberg, H. \& Mueller-Dombois, D. (1966) A key to Raunkiaer plant life forms with revised subdivisions. Berichte des Geobotanischen Institutes der Eidg Techn Hochschule, Stiftung Rübel 37: 56-73.

D’ Arcy, W.G. (1979) Scrophulariaceae. In: Woodson, R.R. \& Schery, R.W. (Eds.) Flora de Panamá. Parte IX. Annales of Missouri Botanical Garden 66: 173-274.

Dyer, A.F. (1963) The use of lactopropionic orcein in rapid squash methods for chromosome preparations. Stain Technology 38: 85-90.

Fernández, A. (1973) El ácido láctico como fijador cromosómico. Boletín de la Sociedad Argentina de Botánica 15: $287-290$.

Grant, V. (1989) Especiación vegetal. Limusa, Mexico, D.F., 587 pp.

Greppi, J.A. \& Hagiwara, J.C. (2011) Una nueva especie de Mecardonia (Plantaginaceae). Darwiniana 49: $43-46$.

Hair, J.B. (1966) Biosystematics of the New Zealand flora, 1945-1964. New Zealand Journal of Botany 4: 559-595.

Hill, J. (1756) The british herbal. T. Osborne and J. Shipton, London, 532 pp. Available from: http://biodiversitylibrary.org/page/34898152 (accessed 1 April 2017)

Raunkier, C. (1934) The Life Forms of Plants and Statistical Plant Geography. Clarendon Press, Oxford, 632 pp.

Linnaeus C (1753) Species plantarum. Salvius, Stockholm, 560 pp.

Linnaeus C (1759) Systema Naturae, Salvius, Stockholm, 984 pp.

Miller, P (1754) The Gardener's Dictionary Abridged. Fourth Edition. P. Miller, London, without pagination.

Miller, P (1768) The Gardener's Dictionary. Eighth Edition. P. Miller, London, without pagination.

Murray, B.G., Meudt, H.M., Tay, M.L. \& Garnock-Jones, P.J. (2010) New chromosome counts in New Zealand species of Plantago (Plantaginaceae). New Zealand Journal of Botany 48: 197-204.

https://doi.org/10.1080/0028825x.2010.515598

Otto, S.P. \& Whitton, J. (2000) Polyploid incidence and evolution. Annual Review of Genetics 34: 401-437. https://doi.org/ 10.1146/annurev.genet.34.1.401

Pennell, F.W. (1946) Reconsideration on the Bacopa-Herpestis problem of the Scrophulariaceae. Proceedings of the Academy of Natural Sciences of Philadelphia 98: 83-98.

Ranjbar, M. \& Nouri, S. (2015) Biogeography of the genus Linaria (Plantaginaceae) based on chromosome number data. Journal of Cell and Molecular Research 7: 115-132.

https://doi.org/ 10.22067/jcmr.v7i2.41375

Rossow, R.A. (1987) Revisión del género Mecardonia (Scrophulariaceae). Candollea 42: 431-474.

Ruiz, L.H. \& Pavon, J.A. (1794) Prodromus flora peruviana et Chilensis. Sancha, Spain, 116 pp. 
Small, J.K. (1903) Flora of the Southeastern United States. J.K. Small, New York, 1370 pp.

Soltis, D.E., Soltis, P.S. \& Tate, J.A. (2004) Advances in the study of polyploidy since plant speciation. New Phytologist 161: $173-191$. https://doi.org/10.1046/j.1469-8137.2003.00948.x

Sosa, M.M. \& Seijo, G. (2002) Chromosome Studies in Argentinean Species of Stemodia L. (Scrophulariaceae). Cytologia 67: $261-266$. http://doi.org/10.1508/cytologia.67.261

Sosa, M.M., Seijo, G. \& Fernández, A. (2009) Chromosome studies in South-American species of Stemodia (Scrophulariaceae) and their geographical distribution. Annales Botanici Fennici 46: 389-396. http://dx.doi.org/10.5735/085.046.0503

Sosa, M.M., Panseri A.F. \& Fernández, A. (2011) Karyotype analysis of the southernmost South American species of Stemodia (Scrophulariaceae). Plant Biosystems 145: 472-477. http://dx.doi.org/10.1080/11263504.2011.566250

Sosa, M.M., Panseri, A.F. \& Dematteis, M. (2012) Morphometric analysis of Stemodia hyptoides and S. stricta (Plantaginaceae). Plant Systematic \& Evolution 298: 1315-1323. https://doi.org/10.1007/s00606-012-0638-0

Sosa, M.M. \& Dematteis, M. (2014) Stemodia diplohyptoides (Plantaginaceae, Gratiolae) a new diploid species from the South America. Phytotaxa 186: 271-278. http://dx.doi.org/10.11646/phytotaxa.186.5.4

Sosa, M.M., Angulo M.B., Greppi, J.A. \& Bugallo, V. (2016) Chromosome numbers and DNA content in some species of Mecardonia (Gratiolae, Plantaginaceae). Comparative Cytogenetic 10: 769-780.

https://doi.org/10.3897/CompCytogen.v10i4.10362

Souza, V.C. (1997) Considerações sobre a delimitação de Mecardonia procumbens (Mill.) Small (Scrophulariaceae). Acta Botanica Brasilica 11: 181-189. http://dx.doi.org/10.1590/S0102-33061997000200008

Souza, V. \& Giulietti, A.M. (2009) Levantamento das espécies de Scrophulariaceae sensu lato nativas do Brasil. Pesquisas Botânica 60: $7-288$.

Stebbins, G.L. (1971) Chromosomal evolution in higher plants. Arnold, London, 216 pp.

Subramanian, D. \& Pondmudi, R. (1987) Cytotaxonomical studies of South Indian Scrophulariaceae. Cytologia 52: 529-541. https://doi.org/10.1508/cytologia.52.529

Vargas. P.J., Rosselló, J.A., Oyama, R. \& Güemes, J. (2004) Molecular evidence for naturalness of genera in the tribe Antirrhineae (Scrophulariaceae) and three independent evolutionary lineages from the New World and the Old. Plant Systematics and Evolution 249: $151-172$.

https://doi.org/10.1007/s00606-004-0216-1

Wolfe, A.D., Datwyler. S.L. \& Randle, C.P. (2002) A phylogenetic and biogeographic analysis of the Cheloneae (Scrophulariaceae) based on ITS and matK sequence data. Systematic Botany 27: 138-148. http://dx.doi.org/10.1043/0363-6445-27.1.138

Wong, C. \& Murray, B.G. (2012) Variable changes in genome size associated with different polyploid events in Plantago (Plantaginaceae). Journal of Heredity 103: 711-719.

https://doi.org/10.1093/jhered/ess049 